\title{
8
}
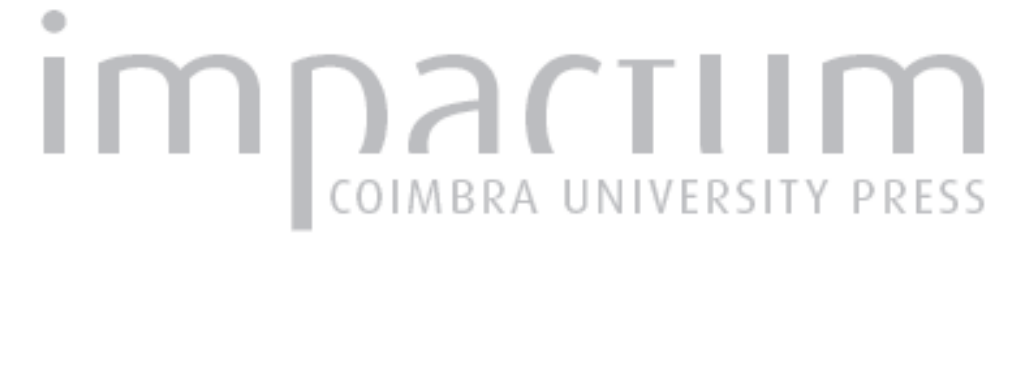

\section{A evolução da ideia de Constituição em Portugal: tentativas constitucionais durante a invasão de Junot}

Autor(es): $\quad$ Santos, Maria Helena Carvalho dos

Publicado por: Imprensa da Universidade de Coimbra

URL persistente:

URI:http://hdl.handle.net/10316.2/43784

DOI:

DOI:https://doi.org/10.14195/2183-8925_10_25

Accessed : $\quad$ 26-Apr-2023 12:34:31

A navegação consulta e descarregamento dos títulos inseridos nas Bibliotecas Digitais UC Digitalis, UC Pombalina e UC Impactum, pressupõem a aceitação plena e sem reservas dos Termos e Condições de Uso destas Bibliotecas Digitais, disponíveis em https://digitalis.uc.pt/pt-pt/termos.

Conforme exposto nos referidos Termos e Condições de Uso, o descarregamento de títulos de acesso restrito requer uma licença válida de autorização devendo o utilizador aceder ao(s) documento(s) a partir de um endereço de IP da instituição detentora da supramencionada licença.

Ao utilizador é apenas permitido o descarregamento para uso pessoal, pelo que o emprego do(s) título(s) descarregado(s) para outro fim, designadamente comercial, carece de autorização do respetivo autor ou editor da obra.

Na medida em que todas as obras da UC Digitalis se encontram protegidas pelo Código do Direito de Autor e Direitos Conexos e demais legislação aplicável, toda a cópia, parcial ou total, deste documento, nos casos em que é legalmente admitida, deverá conter ou fazer-se acompanhar por este aviso.

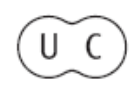


REVISTA DE HISTORIA DAS IDEIAS IO
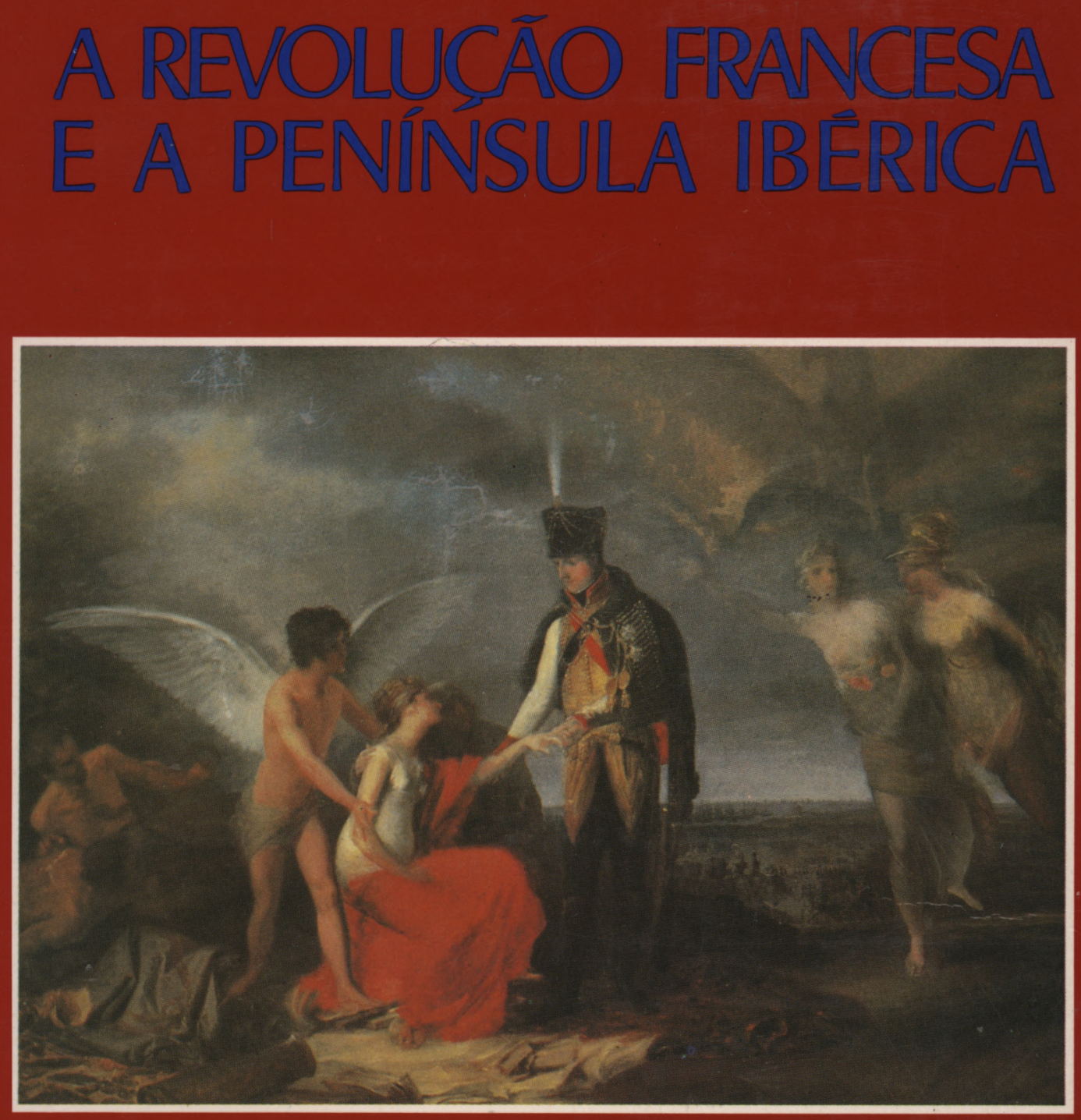

INSTITUTO DE HISTÖRIA E TEORIA DAS IDEIAS FACULDADE DE LETRAS 
MARIA HELENA CARVALHO DOS SANTOS *

\section{A EVOLUÇÃO DA IDEIA DE CONSTITUIÇÃO EM PORTUGAL}

Tentativas constitucionais durante a invasão de Junot **

1. As mutações sociais verificadas na Europa durante a época pombalina e durante o período mariano apontam o tipo de problemas que mais deve ter impressionado a sociedade portuguesa contemporânea.

Das reformas pombalinas à queda da monarquia em França e da Independência dos Estados Unidos da América do Norte e da sua Constituição até aos exércitos que percorriam toda a Europa e invadiram Portugal - tudo revelava o mundo em crise e em transição que havia de motivar grandes alterações na sociedade portuguesa.

$O$ estreito quadro do absolutismo português, com Leis Fundamentais que regiam a sucessão ao trono, mas não detinham mecanismos de relacionamento entre governantes e governados, não podia permanecer imutável.

Foi a época da discussão de todas as grandes questões da sociedade civil, numa espécie de Renascimento, em que já não serão importantes as relações com os deuses, mas são repensadas as relações entre os homens. Se as necessidades de ajuste a uma realidade económica viram nascer o luteranismo, parecia, pelos fins do século XVIII e pelos princípios do século XIX, que a ideia de constitucionalismo era uma força que se impunha como uma necessidade de ordenamento político perante as novas realidades sociais.

Para lá da questão da soberania e da questão da origem do poder (que aparentemente só interessam como discussão

* Faculdade de Ciências Sociais e Humanas da Universidade Nova de Lisboa.

** Esta intervenção foi retirada de um trabalho mais vasto, em preparação, sobre o constitucionalismo português. 


\section{Revista de História das Ideias}

teórica) é a discussão prática do enquadramento político da sociedade que parece tocar a realidade quotidiana do grupo mais próximo do poder ou do grupo mais apetente à sua aproximação. Ambos os grupos estão atentos e é por isso que a questão política centra em si o máximo de atenções e de interesses. Como em outras épocas ainda voltará a acontecer, tudo parecia dependente de uma reformulação política na administração e atribuição dos poderes para se atingir uma harmonia social.

No século anterior, tanto no campo prático, como no teórico, tinha-se afirmado um outro conceito - o das nacionalidades. Será um problema com ramificações e desenvolvimentos em séculos futuros, mas que define, em torno do direito das gentes, a problemática da convivência internacional. As nações podem medir-se, isto é, avaliar a sua força e grandeza, e afirmar-se de igual a igual na base da força militar e dos exércitos nacionais, numa relação demográfica que também traduz poder económico e pode determinar políticas de independências nacionais e de negociações económicas e diplomáticas. Perante uma igualdade conceptual entre as nações pode nascer a questão de uma igual apetência ao poder por parte dos homens que conhecem os mecanismos do poder?

O desenvolvimento do absolutismo criara a noção de igualdade dos vassalos perante o rei. Desse passo se caminha para a questão da igualdade perante a lei. Mas é preciso que a lei se ajuste e sirva novos interesses. É a questão central e primeira do constitucionalismo, que numa abstracção teórica imagina uma nova sociedade, que, afinal, já é uma realidade.

Quando o problema é detectável, assiste-se à definição teórica da ideia de Constituição para se chegar à situação prática da elaboração da primeira Constituição Política da Monarquia Portuguesa.

Em Portugal, entre $1788\left({ }^{1}\right)$ e 1820 , a palavra constituição evoluiu do plano jurídico e orgânico para o plano político e revolucionário, alcançando semelhança de significado na linguagem política e jurídica numa aproximação de significado po-

(1) José Esteves Pereira, António Ribeiro dos Santos, o pensamento filosófico-político, Universidade de Coimbra, 1980, tese de doutoramento. $O$ decreto que nomeia José de Seabra da Silva presidente da Comissão de redacção do projecto é de 12 de Janeiro de 1784, mas é de Julho de 1788 o aviso dirigido a António Ribeiro dos Santos para se deslocar a Lisboa e participar nos trabalhos. Por isso fixamos essa data como início da problemática portuguesa sobre uma primeira ideia constitucional. 
lítico e filosófico. Essa necessidade de aggiornamento é nítida, um pouco mais tarde, em Pedro I do Brasil, quando escreve:

"Amo a liberdade, e se me visse obrigado a governar sem
uma constituição, imediatamente deixaria de ser Impe-
rador, porque quero governar sobre coraçôes com brio, e
honra, corações livres, e não sobre corações lodosos, podres
e servis, como os daqueles povos aonde ainda não há
Constituição».

Quando D. Pedro assim escreve não havia Constituição em Portugal, mas vivia-se um tempo em que o próprio rei, D. João VI, mesmo tendo destruído a Constituição de 1822, é sensível à questão, ao menos no plano teórico, tendo acompanhado pessoalmente parte do percurso da discussão.

Enquanto não é possível chegar à Constituição Política da Nação, e na sequência das discussões e dos vários posicionamentos, o conceito evoluiu.

2. Com os exércitos de Napoleão às portas de Lisboa, o Príncipe Regente, futuro D. João VI, embarca para o Brasil acompanhado de 15000 pessoas.

A hipótese remota ou a necessidade urgente da Corte se deslocar de Lisboa para o Brasil fora várias vezes considerada ${ }^{(2}$.

(2) Tobias Monteiro, História do Império - A Elaboração da Independência, Editora da Universidade de São Paulo, Belo Horizonte, 1981, T. I, p. 56: "Com a morte do Cardeal D. Henrique em 1580, o Prior do Crato pretendeu ascender ao trono; mas Filipe II de Espanha proclamou-se o legítimo herdeiro da coroa e suas forças, sob o comando do Duque de Alba, invadiram Portugal. D. Pedro da Cunha, a quem D. Sebastião deixara em Lisboa como capitão-general, aconselhou o prior a passar-se com os seus para o Brasil e aí fundar um Império. D. Luís da Cunha, o famoso diplomata e neto do capitão-general, também era de opinião que o Brasil deveria ser refúgio da família real em caso de perigo na Europa.

Querendo acautelar-se contra a hipótese de mau êxito na gloriosa empresa da restauração do Reino, absorvido pela Espanha, D. João IV, fundador da dinastia de Bragança, tomara disposições para buscar no Brasil salvação para a sua descendência. Quando Luis XIV casou com uma filha de Filipe IV de Espanha e declarou já não haver Pirinéus, receou-se a divisão de Portugal entre aqueles dois soberanos conquistadores. Então 9 padre António Vieira aconselhou a passagem da sede da Monarquia para o Brasil. Era ainda corrente que Alexandre de Gusmão dera a mesma ideia a D. João V e D. José chegara a ter a esquadra pronta para atravessar o oceano em 1762, quando Portugal foi invadido por dois exércitos, de França e Espanha. Também Silvestre Pinheiro, mais tarde ministro de $\mathrm{D}$. João VI, representara ao régio trono, após a ameaça desfechada sobre a Europa pela usurpação napoleónica, sustentando a opinião de não restar à coroa outro recurso 


\section{Revista de História das Ideias}

Crises políticas na Europa ou simplesmente na Península faziam vir ao de cima a importância da colónia americana. Só o Brasil fora mira ou ponto de referência para a necessidade de um abandono da capital europeia. Assim, no campo da discussão, não tinha grande novidade a resolução apontada e seguida em 1807.

Perante as ameaças napoleónica e espanhola, e perante a inexistência de um exército português capaz de se lhes opôr, parecia fácil ou pelo menos adequado, tomar a decisão de partir para salvar a família real, se não fosse possível salvar o reino.

A diplomacia movimentava-se.

A entrada em Portugal de um exército invasor parecia ser a única pedra certa no complicado xadrez peninsular. Nem o perigo eminente nas fronteiras terrestres, nem o bloqueio marítimo, aconselhavam delongas, mas as negociações arrastavam-se e a hesitação parecia instalada em toda a gente. O representante da Austria "chegou a acreditar, e comunicou ao seu governo, que Portugal se levantava de longa letargia e revelava animada actividade». Admitia ele que «numa semana poderia ter 40000 homens em armas na fronteira». Constava-lhe que «em Peniche, perto de Mafra e a sete milhas de Lisboa, já estavam reunidos 7000 para servirem de base à concentração, em caso de desastre». E acrescentava: "Aí, pelo menos, poderia negociar-se uma capitulação honrosa e dar tempo ao embarque da Família Real para o Brasil».

As negociações e simultaneamente o segredo de Estado passavam pelos Embaixadores, pelos Conselheiros e pelos membros da Família Real cujas viagens e deslocações eram seguidas atentamente como indicadores do que se estava a passar.

Foi neste contexto que a viagem do jovem $D$. Pedro esteve marcada para o dia 30 de Outubro de $1807\left({ }^{3}\right)$.

Aceitando que as fontes diplomáticas eram as mais bem informadas, não resta dúvida que a saída da Família Real estava decidida. Tudo o resto era ganhar tempo e uma questão de pormenor. Era «opinião corrente em Lisboa que o inimigo se

senão o de procurar quanto antes nas suas colónias um asilo contra a hidra nascente, que jurava a inteira destruição das Monarquias da Europas.

Também a Espanha viu nas suas colónias da América um refúgio para situações políticas delicadas, como refere Tobias Monteiro em relação a Filipe V e "aos tesouros do México». O.T. de Sousa, ob. cit., p. 22.

(3) T. Monteiro, ob. cit., p. 34, refere o documento existente no Departamento de Estado de Washington, datado de 16 de Outubro. 


\section{Ideia de Constituição}

aproximava da fronteira, que o Príncipe Regente abandonaria o país, saindo por Peniche ou por outro porto, mas nunca pela foz do Tejo com receio de provocar comoção popular» (4).

A última decisão cabia ao Príncipe Regente que mantinha negociações com o governo inglês e junto de Napoleão, numa política bifronte, intolerável para o Imperador e tendenciosa para com a aliança inglesa.

A 19 de Agosto o Ministro Araújo comunicara a Lord Strangford que "o Príncipe jamais anuiria à exigência de deter os súbditos ingleses e confiscar-lhes os bens» $\left(^{5}\right)$. Efectivamente, só depois de alguma hesitação fora facilitada a saída dos ingleses residentes em Portugal e dos seus bens, tendo havido uma primeira atitude tendente a corresponder ao ultimatum francês. $\mathrm{O}$ embaixador dos Estados Unidos viria depois a admitir que teriam sido cerca de 2000 os ingleses que haviam abandonado o país e que o transporte fora efectuado por mais de vinte navios ingleses e americanos.

A política portuguesa não se decidia, jogava, usando uma «espertesa saloia», como escreve Oliveira Martins, no meio dos muitos altos interesses europeus.

Em Lisboa não faltavam informações. Os ministros portugueses, colocados nas cortes estrangeiras, estavam atentos. $O$ que acontecia era que o governo português não queria acreditar em «más notícias».

António de Araújo de Azevedo ( $\left.{ }^{6}\right)$, Conde da Barca, tinha alguma experiência diplomática, talvez não muito satisfatória, já que fora ele que assinara em 1797 (10 de Agosto) o Tratado de Neutralidade com o governo da Convenção e que não receberia ratificação em Lisboa. Ele havia trabalhado pela neutralidade e pela paz, mas os ventos da História não lhe eram favoráveis. A negociação seria sempre difícil (impossível?), porque neutralidade para com uma das potências em beligerância queria necessariamente dizer guerra declarada à outra, dados os compromissos portugueses assumidos anteriormente e também

(4) T. Monteiro, ob. cit., p. 33.

(5) T. Monteiro, ob. cit., p. 26.

(8) António de Araújo de Azevedo (17541817), 1. Conde da Barca, "literato, cientista e diplomata. Foi um dos principais conselheiros da partida da corte para o Rio de Janeiro, em 1807n, in Dicionário de História de Portugal, direcção de Joel Serrão. Era Ministro de Portugal em Haia quando em sua casa se refugiou, entre 1792 e 1797, o poeta Filinto Elysio. V. Carlos Olavo, A vida amargurada de Filinto Elysio, Guimarães \& C., Lisboa, 1944. O «fundo Barca-Oliveira» existente na Biblioteca Municipal de Braga tem por origem a biblioteca iniciada pelo diplomata português. 
devido à posição estratégico-geográfica de Portugal, perante a Inglaterra e a França e os Impérios coloniais ultramarinos.

$\mathrm{E}$ era essa posição e os interesses dos ingleses aqui radicados que suportavam as negociações com os franceses, já que estes tinham que penetrar por terra, lenta e dolorosamente, para chegar à capital e não queriam encontrar os resultados de uma política de terra queimada, como, afinal, veio a acontecer sucessivamente, mas principalmente no decorrer das duas últimas invasões francesas ( $\left.{ }^{7}\right)$.

As questões levantadas e o quadro estratégico necessitavam, certamente, da parte de Portugal, de um Estado Maior que não existiu. Mas, como em outras épocas, iniciaram-se diligências para a defesa. As «linhas de Torres», construídas sob pressão em 1810 e toda a política militar delas decorrente, não é admissível, como prática e organização, três anos antes. Naturalmente que se Portugal tivesse outro rei, se a hesitação tivesse sido ultrapassada, se tivesse havido um compromisso ibérico, ou se um exército português tivesse afrontado o invasor, como propunha D. Rodrigo de Sousa Coutinho, no Conselho de Estado, o percurso da História seria certamente outro, já que diversas solucões iam sendo apresentadas para enfrentar as mesmas dificuldades. Deveremos talvez referir «uma sugestão intermédia que ocorreu por esse tempo: mandar para o Brasil o Príncipe D. Pedro e duas infantas» $\left(^{8}\right)$. A necessidade de proteger o Brasil podia ser entregue ao jovem Príncipe enviado como símbolo de um poder?

Este plano foi discutido e até provisoriamente aceite pelo Príncipe Regente que o comunicara a Carlota Joaquina. A Princesa não queria fazer a viagem para o Brasil. Preferia regressar a Espanha e nesse sentido se dirigia em cartas desesperadas aos pais, ainda em 27 e 30 Setembro e 9 de Outubro.

(7) No início do século XIX ainda se fazia a guerra como a fizeram os romanos: os soldados percorriam as grandes distâncias em comboios de homens e armamentos, contando, para sobreviver, com o fornecimento de mantimentos para homens e animais pelas populações ou reservas indígenas. A conquista da capital parecia essencial para dominar um país e aí se dirigiam os exércitos. O país invadido, entretanto, podia dar batalhas que mesmo ficando indecisas em relação a uma vitória imediata, pendiam sempre a favor do país invadido, que ganhava tempo, se organizava e destruía lentamente o exército invasor. Isto foi essencialmente claro nas 2." e 3." invasões francesas em que Soult e Massena já não alcançaram Lisboa. Não aconteceu assim durante a incursão de Junot, que chegou a Lisboa sem encontrar resistência.

(8) Octávio Tarquínio de Sousa, História dos Fundadores do Império do Brasil, a Vida de D. Pedro, Rio de Janeiro, Livraria José Olympio Editora, 1972, 7 vols., vol. II, T. I, p. 22. 


\section{A mulher do futuro D. João VI escrevia:}

«....pido a V.M. que se acuerda y que tenga compasion de esta pobre higa, pues me veo rodeada de 8 higos, y que estes pobres inocentes no tienen culpa de nada" ( ${ }^{9}$. E "Ayer depues q. yo habia escrito a VV.MM. me dixo el Principe q. queria q. três de los Chicos fuessem para el Brasil, para dar un seguro a los Ingleses, q. a todo o tiempo fuesse necessario hiriamos todos para allá; yo Senhora no queria hecharme en un pozo, pues yendo tengo allá cierta mi ruina.... VV.MM. pueden sacarme del pricipicio, intimando al Principe que quieren que yo y las higas que yo quisiera llevar vavamos a estar con VV.MM. para tener un seguro del mismo modo a se haze a los Ingleses" (10). Escreve, ainda: "Lhena de afflicion voi a los Pies de VV.MM. a renovar mi suplica, a me livre de hir a morir y a las 4 inocentes higas, y tambien livrarme de algun insulto, manden VV.MM. dezir al Principe que quieren absolutamente aue yo vaya para su compania con aquellas higas que yo quisere llevar.... y esto quanto antes por que ya mis hioos estãn para ir, y tienen todo embarcado $v$ en ellos partiendo se effectua su projecto, que es mandarme como repudiada» (11).

Houve um momento em que a decisão parecia tomada, já que o Príncipe Regente escrevia uma proclamacão aos brasileiros. naturalmente nunca divuloada, em que lhes confiava o filho primngénito «que eles deveriam avaliar como inestimável penhors (12).

Era a necessidade de assegurar no Brasil uma continuidade monárauica, ou a de um regime que garantisse os interesses dos incleses, por oposicão dupla: ao regime republicano dos Estadns Unidos da América e à hipótese de abertura dos portos à Franca através da Espanha.

As reuniões do Conselho de Estado, as deslocacões de membros da família real, as notas e cartas do ministro Araújo $\left.{ }^{13}\right)$ e as contradirões diplomáticas, deixam entender a «decisão» de enviar ao Brasil o pequeno Príncipe de 9 anos. feito Condestável. acompanhado por D. Fernando de Portugal, futuro Marquês de Aguiar. A decisão surgia como uma daquelas medidas que são tomadas porque alguma coisa era preciso decidir.

D. João, enquanto príncipe, ou rei, será acusado pelos historiadores de indeciso. Mas era hábil em ganhar tempo,

(श) O. Tarquínio de Sousa, ob. cit., p. 31.

(10) Idem.

(11) Idem.

(12) T. Monteiro, ob. cit., p. 31.

(13) No Arquivo Imperial de Petrópoles. 
esperando simplesmente ou aguardando que as crises se resolvessem a seu favor. Também desta vez $\mathrm{D}$. João não chegou a dar a última ordem, mesmo quando Strangford se mostrava satisfeito com aquela solução.

D. João foi pedindo conselho, foi resolvendo sozinho, como quando decidiu fechar os portos portugueses aos navios ingleses. Teve tempo para acalentar projectos, visionar soluções, deitar contas à vida. E se a sua própria formação, física e mental, o levaram a pretender a solução menos incómoda e a evitar uma longa viagem e uma adaptação a condições desconhecidas - a decisão de enviar o príncipe D. Pedro em que é que o vinha favorecer ou à questão portuguesa? Não encontro motivos razoáveis para essa partida em substituição da ida de toda a família real. Porque se tudo corresse bem, então nenhuma medida de excepção seria necessária. E se a família real fosse «vexada» pelos exércitos inimigos qual era a justificação para sacrificar o Príncipe Regente, fazendo-o ficar? Aquela decisão de enviar D. Pedro para o Brasil, como representante e Senhor da Casa de Bragança só tinha justificação se em Portugal o tronco principal da família se mantivesse. Nem no domínio das hipóteses nos cabe ponderar a ideia do sacrifício do futuro rei João VI - salvando-se a casa reinante através do primogénito que guardaria para si a coroa no Brasil. Seria um artifício de pensamento que nada justificava. $\mathrm{E}$ se havia que fugir ao invasor, tudo aconselhava a evitar «vexames» às cabeças coroadas e a terem de ir, deviam ir todos, como afinal aconselhava a Rainha, num momento de lucidez. Então, o Príncipe Regente deve ter «aceitado» e «acarinhado» a ideia da partida de seu filho D. Pedro como uma ideia que mais uma vez lhe permitia ganhar tempo, tomando aparentemente uma decisão - isto é, ocupando o lugar que pretendiam todos que ele tomasse de responsável máximo dos destinos de Portugal. Aparentemente ele tinha cumprido essa obrigação - tinha tomado uma decisão. Mas uma decisão que não era importante para Portugal - apenas revelava uma concepção monárquica de respeito à lei tradicional. O primogénito era o herdeiro. A ele era confiada a missão de representação e de sucessor. Mais tarde se repetirá este pensamento, quando D. João VI regressar a Portugal, em 1821, deixando no Brasil o filho primogénito. Naturalmente, era este o destino do Príncipe desde o dia da morte de seu irmão mais velho o Príncipe D. António. A sucessão do trono pelo filho mais velho era uma das leis tradicionais portuguesas e que quase todos queriam respeitar. A partilha do poder ou, pelo menos a sua bifurcação, aceita-a D. João (em relação ao próprio filho, como na prática acontecia em 
relação à mãe), em 1807, como um paleativo e em 1821 como uma necessidade. Comparamos aqui estes dois tempos que fazem parte do pequeno drama então vivido pela monarquia portuguesa para reforçar a ideia da complexidade da situação e para, desde já, apontar o papel determinante ocupado por D. Pedro - papel que ele sempre ocupará tendo em atenção mais as leis tradicionais da hereditariedade do que as leis da legitimidade.

Entre as hesitações dos partidos $\left({ }^{14}\right)$ prevalecia a opinião de António Araújo que se batia decididamente pela saída da Corte para o Brasil, o que permitiria «conservar intacta a integridade das possessões ultramarinas» $\left({ }^{15}\right)$. Isto é, o Brasil «de cuja riqueza dependia a metrópole, era a preocupação máxima da Corôa e dos seus conselheiros» $\left({ }^{16}\right)$, sendo «Portugal uma consequência dos desccbrimentos marítimos» $\left({ }^{17}\right)$ e orientando a sua acção em função do Império. Foi assim até à independência do Brasil e foi assim depois, entre o século XIX e o

(14) Oliveira Ramos, «D. Francisco de Lemos e a deputação a Baiona", in Estudos de História de Portugal, Homenagem a A.H. Oliveira Marques, vol. II, - sécs. XVI-XX, Lisboa, Editorial Estampa, 1983, pp. 273-288. Oliveira Ramos considera que em Portugal, ao tempo das invasões francesas, emergiam cinco tendências principais: 1-os que acusavam a negligência do governo porque não tinha previsto a hipótese de guerra; 2 - os que apoiavam a retirada da corte para o Rio de Janeiro; 3 - os que se queixavam da política inglesa que apenas cuidava de defender o Brasil; 4 - «uma classe de homens totalmente ignorantes das coisas do Estado" que "atribuiam à traição e venalidade de um dos mais hábeis ministros do Gabinete" a desgraça do príncipe e da nação; 5 - os malcontentes do governo que admitiam vícios anteriores e "chegavam a conceber esperanças de que um governo novo e enérgico... seguiria melhor caminho». "Demandavam novo sistema de leis constitucionais», pp. 176 e ss., de um doc. inédito de Fr. Francisco de S. Luis, Notas sobre a revolução de Portugal.

(15) T. Monteiro, ob. cit., p. 28.

(16) Idem, p. 31.

(17) Araújo, Cartas dirigidas a José Egídio, no Arq. do Castelo d'Eu, in T. Monteiro, ob. cit., p. 30. Joaquim Barradas de Carvalho, O Renascimento Português, Lisboa, Imprensa Nacional - Casa da Moeda, 1980, p. 13: "Os Descobrimentos são o facto essencial do Repascimento; não teríamos mesmo necessidade da autoridade de Georges Lefebvre para o afirmar. E Portugal não pode ser compreendido no que tem de específico sem os Descobrimentos $\mathrm{e}$, em consequência, sem o seu Renascimento. O Renascimento português é a placa giratória da história de Portugal. O Portugal de antes, da Idade Média, era já uma preparação para o seu Renascimento, o Renascimento português. 0 Portugal de depois, da época moderna e contemporânea, é uma consequência dos descobrimentos marítimos, do seu Renascimento....». É assim que pensa Barradas de Carvalho que se considerava, ele próprio, um luso-franco-afro-brasileiro. 


\section{Revista de História das Ideias}

século XX, do mapa-cor-de-rosa à independência das colónias de Africa.

$\mathrm{Na}$ necessidade de tomar resoluções davam-se ordens, mas parecia faltar o dinheiro. Preparava-se e dissimulava-se a viagem da família real. Partiam 15000 pessoas, diz Oliveira Martins e todos os historiadores parecem concordar, tomando por indicativo os bens que então foram transferidos para o Brasil e de que dão testemunho as bibliotecas e arquivos brasileiros. Pereira da Silva $\left({ }^{18}\right)$, Tobias Monteiro $\left({ }^{19}\right)$, Oliveira Lima $\left({ }^{20}\right)$ entre outros historiadores brasileiros calculam que mais de oitenta milhões de cruzados. metade do dinheiro em circulação no reino, foram levados pela comitiva, em valores públicos e particulares $\left.\mathbf{( 2 1}^{\mathbf{2}}\right)$.

As personalidades que acompanhavam a família real, além do Infante de Espanha, D. Pedro Carlos, eram as seguintes: os Duques de Cadaval (o duque morreu pouco depois de chegar ao Brasil). os Marqueses de Angeia, Vagos, Lavradio, Alegrete, Torres Novas Pombal e Belas; os Condes de Redondo, Caparica, Belmonte. Calvário; o Visconde de Anadia: o ministro e secretário de Estado dos Negócios ultramarinos, D. Rodrigo de Sousa Coutinho; António de Araújo de Azevedo, ministro dos Negócios Estrangeiros e da Guerra; D. João de Almeida. Viajavam ainda monsenhores, mestres de cerimónias, tesoureiros, desembargadores, oficiais. Por razões de saúde, ou pelo menos de idade, não acompanhou a comitiva o preceptor de D. Pedro ${ }^{(22)}$.

Posteriormente, viajaram as rendas.

Mas nas vésperas da partida tudo parece ter sido tentado para ficar, embora essas negociações fossem mais um artifi-

(18) Pereira da Silva, Os filhos de el-Rei D. João VI.

(19) M. Oliveira Lima, D. João VI no Brasil-1808-1821, Rio de Janeiro, Livraria José Olympio Ed., 1945, 3 vols., $O$ Movimento da Independência (1821-1889), Livroluz Divulgadora Cultural, 4.: ed.

(20) Tobias Monteiro (1866-1952), História do Império - O Primeiro Reinado, Belo Horizonte, Editora da.Universidade de São Paulo, 1982, 2 vols.

(21) Francisco Luiz Teixeira Vinhosa, História Administrativa do Brasil-Brasil Sede da Monarquia-Brasil Reino (2.: parte), Brasília, FUNCEP, 1984, p. 17.

(22) Sobre o comportamento de D. Pedro, Príncipe da Beira, durante a viagem ver 0 . Tarquínio de Sousa, ob. cit., pp. 39 e ss. O preceptor de D. Pedro tinha sido o Dr. José Monteiro da Rocha, jesuíta, que por motivos de saúde ou outros não acompanhou a comitiva. Frei António de Arrábida é o novo preceptor. V. Eugène de Monglave, Correspondance de Don Père Premier, Introdução. 
cialismo, como a hipótese de oferecimento de casamento do Príncipe D. Pedro com a filha de Murat $\left({ }^{23}\right)$.

Aos portugueses, o Príncipe proclamava no dia 24 de Novembro:

«Tendo procurado por todos os meios possíveis conservar a neutralidade, de que até agora têm gozado os meus fiéis e amados vassalos e apesar de ter exaurido o meu Real Erário, e de todos os meus sacrifícios a que me tenho sujeitado, chegando ao excesso de fechar os portos dos meus reinos aos vassalos do meu antigo e leal aliado, o rei da Grã-Bretanha, expondo o comércio dos meus vassalos à total ruína, e a sofrer por este motivo grande prejuízo nos rendimentos da minha coroa: vejo que pelo interior do meu reino marcham tropas do imperador dos franceses e rei da Itália, a quem eu me havia unido no Continente, na persuasão de não ser mais inquietado; e que as mesmas se dirigem a esta capital. E querendo eu evitar as funestas consequências que podem seguir de uma defesa, que seria mais nociva que proveitosa, servindo só de derramar sangue em prejuízo da humanidade, e capaz de acender mais a dissenção de umas tropas, que têm transitado por este reino, com o anúncio e promessa de não cometerem a menor hostilidade; conhecendo igualmente que elas se dirigem mui particularmente contra a minha real pessoa, e que os meus vassalos leais serão menos inquietados, ausentando-me eu deste reino: Tenho resolvido, em benefício dos meus (24) vassalos, passar com a rainha minha senhora e mãe e com toda a real família para os Estados da América, e estabelecer-me na cidade do Rio de Janeiro, até a paz geral» (25).

\section{O rei de Portugal deixava de ser rei de Portugal - e abdicava no desconhecido?}

(23) «Notícias assustadoras trouxera de Paris D. Lourenço de Lima, ministro português ali acreditado. Não era possível deixar de satisfazer as exigências francesas. E o Príncipe regente deu uma guinada contra os ingleses assinando a ordem para a detenção dos súbditos britânicos e o confisco de seus bens (embora se pretendesse indemnizá-los depois por detrás da porta), ao mesmo tempo que tentava num golpe simplório transmudar os propósitos de Napoleão por meio de fascinantes presentes e ofertas sedutoras. O Marquês de Marialva foi nomeado embaixador em missão especial junto do imperador e, levando na sua bagagem diamantes de extraordinário valor, recebera instruções para propor o casamento de D. Pedro com uma sobrinha de Napoleão, filha de Murat», in O. Tarquínio de Sousa, ob. cit., p. 26.

(24) Como concepção de soberania deve ter-se em atenção que neste texto se usa 12 vezes o conceit $m e u$, minha e todo o texto interpreta um sentido paternalista da relação rei/vassalos.

(25) Este texto é transcrito por vários historiadores. Seguimos José d'Arriaga, História da Revolução Portuguesa de 1820, Porto, 1901, vol. I, pp. 528-529, embora corrigindo alguns erros tipográficos. 


\section{Revista de História das Ideias}

3. Numa directa dependência dos acontecimentos franceses, vejamos como em Portugal se faziam as primeiras tentativas para levar à prática a ideia de Constituição durante a invasão de Junot.

Em Porugal ficavam, com encargos de regência: D. Francisco da Cunha Menezes, marquês de Abrantes e tenente-general dos exércitos; o Principal Castro; Pedro de Melo Breyner; Luis de Vasconcelos e Sousa; D. Francisco de Noronha, o Conde Monteiro-Mor; o Conde de Sam-Paio; D. Miguel Pereira Forjaz; João António Salter de Mendonça.

Junot substituiu esta regência de nomeação régia por um ministério francês, acolitado por Pedro de Melo Breyner, o Conde de Sam-Paio e o Principal Castro.

Em 13 de Dezembro de 1807, no Castelo de S. Jorge era hasteada a bandeira francesa.

Numa relação Portugal-Brasil podia dizer-se que a capital do reino era transferida para o Brasil e que tem razão de ser a expressão que passou a identificar uma situação, isto é, que Portugal era a Colónia da Colónia... A situação é tão complexa que essa crítica, só por ela não corresponde à totalidade da questão. Na realidade, depois de Junot-rei é Beresford o governador de Portugal. Mas mantêm-se as aparências: governa-se em nome de $D$. João enquanto se mantem um exército de 60000 homens. Portugal era, efectivamente uma colónia da Inglaterra, enquanto no Brasil se conjugavam os interesses britânicos com as directrizes de Metternich.

Junot chegava a Lisboa sem encontrar resistência e, em Lisboa, via-se rodeado das mais altas personalidades que, aparentemente, obedeciam a ordens do Príncipe Regente português. Junot, por sua parte, respeitava as indicações de Napoleão, criando a Legião Portuguesa, que permitia fazer seguir alguns portugueses para um exílio prestigiado.

Em Portugal verificava-se um decréscimo demográfico. A revolta ia organizar-se e iniciava-se a discussão da ideia de suberania nacional, que se deslocava do rei para a nação.

Afastados os militares, Junot extingue o Conselho da Regência e nomeia o novo Intendente Geral da Polícia, Lagarde $\left({ }^{26}\right)$. A Napoleão é enviada uma deputação que lhe devia solicitar clemência para o país ocupado. A embaixada era composta por personalidades destacadas, que uma vez fora do país, seriam retidas em França durante anos $\left({ }^{27}\right)$. Esta deputação,

(26) Gazeta de Lisboa, 5 de Abril de 1808; decreto de 25 de Março.

(27) Luís A. Oliveira Ramos, ob. cit., p. 283: Napoleão «recomendou aos delegados que se estabelecessem em Bordéus....». Sobre o 
que tem suscitado algumas opiniões contraditórias a propósito do desempenho patriótico da sua missão $\left({ }^{28}\right)$ era constituída pelos Marqueses de Abrantes, Marialva, Penalva e Valença, pelo bispo-conde de Coimbra, D. Francisco de Lemos, pelo bispo do Algarve, D. Nuno Álvares Pereira, irmão do Duque de Cadaval, pelos Conde de Sabugal e visconde de Barbacena, D. Lourenço de Lima, por Tomás da Silva Leitão e pelo desembargador Joaquim Alberto Jorge.

A situação mantinha-se ambígua. Junot fora acolhido por uma Regência que a recebia em nome do Príncipe, mas na realidade havia um trono vago e um estado governado por decretos avulsos.

4. Era natural que, perante o prolongamento da crise, fosse recuperada a discussão sobre a organização política do país.

Surgem vários grupos de pressão e as respectivas propostas para uma solução política para Portugal que se desenvolvem em várias frentes:

1. O grupo do Conde da Ega, procurando ir ao encontro dos desejos íntimos de Junot.

2. O grupo de Seabra da Silva, recuperando a ideia de reunião de Cortes.

3. O grupo dos «heterodoxos», afrancesados, mas não adeptos de Junot, que pediam ao Imperador uma Constituição (semelhante à da Polónia) e um «rei constitucional» que fosse príncipe da família de Napoleão.

4. O grupo do Norte do país que reúne a Junta Provisional do Supremo Governo do Reino e que inicia conversações com a Inglaterra para uma ajuda militar.

Num assomo de soberania, Junot mandou reunir a Junta dos Três Estados, isto é, as «Cortes de Lamêgo», como escreve Oliveira Martins.

Aceitamos que em reunião secreta e antecipada se tivesse decidido e elaborado um texto que recolheria as seguintes

mesmo assunto, António Ferrão, A 1.a Invasão Francesa, Coimbra, Imprensa da Universidade, 1923, p. CCLXIII, escreve: «....deixemos a deputação portuguesa passando de Baiona para Bordéus e daí para Paris até ao estabelecimento da paz geral, em 1814».

(28) Oliveira Ramos, ob. cit., p. 275: «....que entre os nacionais lhe valeu o apodo de colaboracionista». Rocha Martins, no entanto, considera-os prisioneiros. Escreve: «....marqueses.... que o tinham servido tão rasteiramente em Portugal e agora estavam em Bordéus quasi prisioneiros", in A côrte de Junot em Portugal -1807-1808, Lisboa, Livraria Central de Gomes de Carvalho, Editor, 1910, p. 93. 
assinaturas: pelo clero, os Principais Noronha e Miranda; pela nobreza, o Conde de Peniche, Presidente do Conselho da Fazenda e D. Francisco Xavier de Noronha, que dirigia a Mesa da Consciência e Ordens; pela Magistratura, os desembargadores Esteves Negrão e Lucas Seabra da Silva; pelos ofícios Abreu Guião, Luís Coelho Faria e José de Abreu Campos, Juiz do Povo. Pelo Município assinaram os Condes da Ega, de Castro Marim e de Almada.

Uma segunda deputação devia levar a Napoleão a proposta da nomeação de um rei (poderia ser Junot, para um grupo, ou ser um outro "príncipe da sua escolha»), o que implicava, de certo modo, pôr a questão da soberania, da independência de Portugal e da sua organização política. É constatar a crise política. As soluções são apresentadas conforme podem resolver os problemas individuais ou de grupo. Portugal apresentava uma série de condicionalismos que levava os grupos próximos do poder a considerar que se podia tentar um ou outro golpe de ordem política. Começa a visionar-se o momento em que uma atitude voluntarista pode substituir uma atitude tradicionalista. Mas não se pretende, ninguém pretende, que essa atitude seja de ruptura com o passado. Os pensadores, que de um momento ao outro podem ser transformados em revolucionários, hesitam e têm medo. Está prestes o momento em que a palavra chega a não se distinguir da acção e a liberdade de expressão pode significar direito à desordem e se é uma revolução que se vai lentamente preparando, os portugueses, jornalistas, militares, estudantes, comerciantes, aristocracia, sentem que estão a caminhar por terrenos difíceis e que pela primeira vez (ao menos depois de muitas gerações) podem, num acto simultaneamente inteligente e de força, «tomar o poder». Parece existir uma dialéctica entre voluntarismo e impotência. Como diz Hobhouse, «aqueles que realizam uma revolução devem saber a onde conduzem o mundo» $\left({ }^{29}\right)$. Precisam ainda de construir ou de divulgar uma teoria que lhes proporcione uma base social de apoio. A crise económica e de administração podia, enquanto tudo é confuso, passar a segundo plano e fazer vir ao de cima apenas a crise de autoridade e de poder - num país ocupado. Perante esta realidade, os vários grupos portugueses como que mantêm latentes as suas questões, mas se vêm obrigados a escolher um partido. Ou a favor de Portugal independente ou a favor dos franceses. A crise era tão profunda que parecia só poder ser vencida por

(29) L.T. Hobhouse, Liberalismo, Barcelona, Editorial Labor, Buenos Aires, 1927, p. 46. 


\section{Ideia de Constituição}

étapes. O grupo francês, em torno de Junot, pensa que uma étape passa pela organização política, pela institucionalização de uma nova casa reinante que lhe traria alguma estabilidade. Mas era a cedência da soberania a um rei estrangeiro. Esta questão pode ser ladeada, recorrendo a uma argumentação político-romântica, recuperando um episódio velho da História de Portugal. Lembrava-se aos portugueses «que o seu primeiro soberano fora o Conde D. Henrique, príncipe francês» $\left({ }^{30}\right)$.

Esta proposta pode corresponder a um arranjo entre ocupantes e vassalos que constituem o grupo francês e que pouco tem a ver com as ideias francesas, avançadas, revolucionárias. Ao contrário, é, de facto, a tentativa de recuperação de um poder forte, assente no exército, na intenção de alterar o equilíbrio peninsular e mesmo europeu, na fase de grande apogeu de Napoleão. A repressão, a violência e os actos contra os portugueses são a prática do tempo de Junot em Lisboa $\left({ }^{31}\right)$.

O grupo que cerca Junot, talvez encabeçado pelo Conde da Ega, procura defender os seus interesses imediatos e assinaria qualquer proposta, principalmente se ela não viesse introduzir uma alteração profunda no sistema e não revelasse uma preocupação de renovação na organização política.

Parecia que a mudança da casa reinante e a sua substituição eram de momento as únicas preocupações, necessidade e urgência. Aceitava-se esta alteração com toda a naturalidade, dado que essa solução política fora facilitada com a ida do rei e da corte para o Brasil.

5. José Seabra da Silva fizera valer tardiamente a sua reivindicação de reunião de Cortes, na necessidade de revitalização de uma prática esquecida durante séculos, já que a última reunião de Cortes datava de 1697. Esta atitude pode ser entendida como uma certa oposição a Junot, fazendo-lhe reconhecer as forças vitais da nação? Assim se pcderá entender através do episódio do juiz de fora, José de Abreu Campos, porta-voz, na reunião de 23 de Maio de 1808, do grupo de Ricardo Raimundo Nogueira, Reitor do Colégio dos Nobres, do Doutor Guilherme Seixas, de Simão de Cordes Brandão,

(30) Texto da mensagem dirigida a Napoleão, in Rocha Martins, ob. cit., p. 90.

(31) António Ferrão, ob. cit., 2." Parte, Documentos, Correspondência do Intendente Geral da Polícia, Lucas de Seabra da Silva, Tempo Da Dominação Francesa de Junot (1807-1808) e Correspondência do Intendente Geral da Polícia Francês, Pierre Lagarde no Tempo da Dominação de Junot (de 26 de Março a 12 de Julho de 1808). 
de Francisco Duarte Coelho, de Lecusson Verdier $\left(^{32}\right)$ e de Carrion Nizas ${ }^{33}$ ). Mas este grupo afasta-se do compromisso de Seabra da Silva. Entre Seabra da Silva e o grupo do Conde da Ega podia haver um certo entendimento, mas a instabilidade entre eles será introduzida pelos «heterodoxos» que pretendem ultrapassar Junot e pôr condições a Napoleão, na sequência da proposta do juiz de fora.

O grupo dos «heterodoxos» apresentava a seguinte proposta: para rei de Portugal pretendia um familiar de Napoleão (por oposição a Junot) e para a organização do Estado pronunciava-se abertamente, solicitando uma Constituição semelhante à de Varsóvia, embora com nítidas diferenças que permitissem que «os representantes da nação fossem eleitos pelas câmaras municipais», isto é, que permitissem uma eleição secundária e um certo entendimento de liberdade religiosa e de «tolerância civil».

Também esta solução, ao solicitar a Napoleão a outorga de uma constituição, lhe reconhecia implicitamente autoridade e poderes de soberania, ideia que por essa época indiscutivelmente dominava a Europa. Este grupo corresponde ainda, de outro prisma que seja, ao partido francês, pois que também para ele o vencimento de étapes prioritárias passava pela subordinação ao poder napoleónico. Está mesclado, no entanto, de alguns resíduos revolucionário-constitucionais. Admitimos, mesmo, que lhes importasse mais a ideia de constituição do que a figura do rei. Ao analisarmos a evolução da ideia de constituição em relação ao constitucionalismo português, é nesta proposta que se encontram, para este período, as maiores influências do constitucionalismo revolucionário francês e podemos dizer que se trata do $10^{\circ}$ texto sistematizado como proposta de uma Constituição para Portugal.

(32) Verdier foi preso e teve processo. Vide auto de perguntas a Verdier, in A. Ferrão, ob. cit., pp. CCLXV, 361 e 415-417. Verdier foi um dos "heterodoxos".

(33) Sobre Carrion Nizas vide Albert Silbert, Autour de Francisco Solano Constâncio, p. 196. Cf. Georges Boisvert, Un Pionnier de la Propagande Liberale au Portugal: João Bernardo da Rocha Loureiro (1778-1853), tese de doutoramento, Université de Paris-III, Sorbonne Nouvelle, 1979 , p. 145 , nota 142 . Cabe aqui um agradecimento muito especial ao Professor Georges Boisvert que me facultou o texto da sua tese quando ainda estava na tipografia o volume que foi editado com o mesmo título pela Fundação Calouste Gulbenkian, Centro Cultural Português, Paris.

Carrion Nizas, oficial de cavalaria e escritor, é adversário do poder pessoal de Junot e faz propaganda a favor de uma constituição para Portugal in A. Ferrão, ob. cit., p. CCLXV. 
No entanto, não vingou nem a posição mais próxima de Junot, nem a que se lhe opunha. A situação havia, ainda, de se desenrolar prioritariamente no teatro militar e insurreccional em várias frentes.

6. No Norte do país organizava-se a Junta Provisional do Supremo Governo do Reino, formada a 19 de Junho de 1808 e constituída pelas seguintes entidades: bispo do Porto, D. António José de Castro, que presidia e tinha por vogais Manuel Lopes Loureiro, provisor do bispado, José Dias de Oliveira, vigário geral, José de Melo Freire, juiz, Luis de Sequeira Aiala, desembargador dos agravos, António da Silva Pinto, sargento-mor, João Manuel de Mariz, capitão artilheiro e Manuel Ribeiro Braga e António Mateus Freire de Andrade, representantes do povo.

«Esta JUNTA fez uma proclamação em nome do príncipe regente D. João, fazendo saber «a todos os vassalos do dito Senhor que o governo francês se acha inteiramente abolido e exterminado deste país e restituída nele a real autoridade de nosso legítimo soberano, a qual será exercida plena $e$ independentemente pela sobredita Junta em quanto não for restituído o governo instituído, neste reino, por S.A.R.» $\left.{ }^{34}\right)$.

O Campeão Portuguez, periódico editado em Londres a partir de $1819\left({ }^{35}\right)$ publica tardiamente $\left({ }^{36}\right)$ um documento imanado desta Junta e dirigido ao Príncipe D. João. O requerimento não me parece tão importante quanto Georges Boisvert

(34) Correio Braziliense, Londres, 1808, p. 155, 248.273. A. Ferrão, ob. cit., p. CCXCVI.

(35) O Campeão Portuguez ou o Amigo do Rei e do Povo. Jornal político, publicado todos os quinze dias para advogar a cauza e interesses, Londres, 1819. Este periódico de que foi redactor José Liberato Freire de Carvalho é o herdeiro de $O$ Investigador Portuguez em Inglaterra ou Jornal Literario, Politico, etc., Londres, 1811. Jornal oficioso, foi criado para se opor ao Correio Braziliense ou Armazem Literario, Londres, 1807, decano das chamados jornais de Londres. Maria Helena Carvalho dos Santos, "As ideias republicanas em Portugal e o jornalista João Bernardo da Rocha Loureiro (1778-1853)», Arquivos do Centro Cultural, Paris, Fundação Calouste Gulbenkian, XIX, 1983, p. 169; O Pensamento Politico de Rocha Loureiro (1778-1853), Lisboa, Centro de História da Cultura da Universidade Nova de Lisboa, 1982, pp. 7-8.

(36) Georges Boisvert, ob. cit., p. 145, nota 141 «Le texte de ce requerimento a été donnée comme authentique par José Liberato qui l'a publié pour la première fois à Londres dans son Campeão portuguez, Vol. I, pp. 62-68». 


\section{Revista de História das Ideias}

parece considerá-lo $\left({ }^{37}\right)$, mas cabe aqui referi-lo por duas ordens de razões, já que o texto nos suscita algumas dúvidas.

1 -O texto do documento não está em relação lógica com a prática seguida pela Junta. A Junta do Porto não defende nenhuma linha política ${ }^{38}$ ) que entronque na exigência de reunião de Cortes ou na petição a quem quer que seja da outorga de uma constituição. O requerimento dirigido ao príncipe terá sido «escamoteado» $\left({ }^{39}\right)$ pelo Bispo do Porto e Presidente da Junta que manda prender à sua ordem dois dos «supostos redactores» do documento. Esta atitude só é entendível se o documento não veiculasse as decisões e interesses da Junta e fosse um «manifesto» subversivo de um grupo de indivíduos que, no Porto, a coberto da Junta, dirigiam um primeiro Memorial ao príncipe $\left({ }^{40}\right)$. E, de todas as formas um documento clandestino e que parece desconhecer que a Junta dos Três Estados tinha reunido em 23 de Maio.

2 - Por outro lado, a terminologia usada parece-me significativa, uma vez que damos conta que será a primeira vez que encontramos a expressão inconstitucional com o significado de não representativo ou arbitrário.

também interessante que se refira a Constituição inglesa para explicar ao príncipe que o povo e o soberano têm poderes distintos, mas inseparáveis e para lhe lembrar que a decadência do reino se inicia com $\mathrm{D}$. João $\mathrm{V}$. O texto pretende argumentar com as Cortes de Coimbra e as de Lisboa de $\left.1641{ }^{41}\right)$, as Cortes em que os reis portugueses foram entronizados por deliberação popular. Fica, no entanto, também a ideia que foram as Cortes de 1581 que reconheceram Filipe II de Espanha como rei de Portugal. Parece um texto mal construído para manifesto.

Tem interesse porque se pode detectar nele a argumentação que os chamados jornais de Londres irão desenvolver entre 1808 e 1820 .

(37) G. Boisvert, ob. cit., pp. 90 e ss.

(38) A linha política da Junta do Porto tem por vector mais importante uma defesa de Portugal perante o invasor. Paralelamente revela uma atitude conservadora de respeito pela monarquia absoluta. 0 texto em caysa, como se verá, leva à prisão dos seus prováveis autores, por ordem do Presidente da referida Junta.

(si) G. Boisvert, ob. cit., p. 90.

(40) MEMORIAL ou cartas abertas são dirigidas a D. João VI, no Brasil, pelos chamados «Jornais de Londres», relatando-lhe o "estado miserável do reino" e fazendo-lhe sugestões sobre a necessidade de reformas e a necessidade de uma constituição para Portugal.

(41) 0 texto refere 1640 . 
Através do Códice revelado por António Ferrão $\left(^{42}\right)$ e nas Actas das sessões da Junta Provincial do Governo (1808) que fixam as deliberações das Sessões da Junta Provisional da Segurança Pública de Braga tomamos conhecimento do ambiente revoltoso do Norte do País e das preocupações e soluções encontradas para o restabelecimento do Governo conforme com a «Regência criada pelo Principe Regente Nosso Senhor pelo seu Decreto de 26 de Novembro de 1807».

A leitura das Actas apontam-nos quatro grandes questões:

$1 .^{a}$ - a solução militar pela organização e manutenção de um exército;

2. ${ }^{\text {a }}$ - as questões de administração, rendas públicas e manutenção da máquina do Estado;

3. ${ }^{a}$ - a obtenção de apoios ingleses (empréstimos, armas e soldados);

4. ${ }^{\mathrm{a}}$ - a liderança do processo de recuperação da independência, de organização política do Estada e de manutenção da monarquia e da casa de Bragança.

Os pontos 3 e 4 são aqueles que nos interessam analisar em primeiro lugar neste trabalho.

Para dar cumprimento à determinação de negociar apoios em Inglaterra, a Junta decidiu enviar a Londres Luís Máximo Alfredo de Sousa Coutinho, 2. ${ }^{\circ}$ visconde de Balsemão, e o desembargador João Carvalho Martins da Silva Ferrão ( $\left.{ }^{43}\right)$.

$\mathrm{O}$ Visconde de Balsemão, que irá permanecer uma larga temporada em Inglaterra, escreve várias Cartas $\left({ }^{44}\right)$, talvez apenas memórias de viagem, a um Amigo do Coração. E decorrente do pensamento expresso nessas cartas e da análise das actas das sessões da Junta que nos podemos aperceber de uma situação real de transição política, traduzida numa certa evclução conceptual, talvez imperceptível aos próprios participantes.

Se por um lado há a preocupação de considerar as várias Juntas como a reunião de cortes em que estão representados os três estados («todo o Clero, Nobreza e Povo») num apoio total ao Príncipe Regente e no reconhecimento da Junta Central do Porto ou Junta do Supremo Governo, por outro lado há a afirmação de que todas «as Juntas Provisórias do Governo estabelecidas nas diferentes Comarcas» foram de criação independente e entre elas não há subordinação, embora se venha

(42) A. Ferrão, ob. cit., p. CCLXXIX e ss.

(43) Vide Correio Braziliense, pp. 250-251.

(44) A. Ferrão, ob. cit., pp. CCXVII e ss. 
a reconhecer "por suprema a do Porto», na necessidade de centralização governamental, conformando-se, ainda, «aos votos da Nação».

Esta terminologia é ambígua, de transição, entendível numa situação de crise em que o problema militar é prioritário, mas onde subjaz a necessidade de uma nova organização política que já não pode ter como centro e motor a vontade do rei. No entanto, ainda não aderiu à proposta que se desenvolvia em outros sectores ou grupos, tanto em Portugal, como no estrangeiro.

O Visconde de Balsemão escreve, a 7 de Agosto de 1808, sobre as relações que vai estabelecendo com "oficiais escolhidos de entre os portugueses que buscaram neste reino [Inglaterra] refúgio no tempa que sofremos o jugo francês», mas logo a 21 de Setembro refere "algumas dificuldades nascidas do capricho dos homens que vivendo distantes querem governar a seu modo o nosso reino", acrescentando: «Deus acabe com tais inovadores que em lugar da perfeição que querem buscar ao mundo têm concorrido a sepultá-lo em um maior abismo fazendo tornar a classe dos homens a animais mais ferozes...».

Escreve: «Espero que os mais pequenos esforços possam beneficiar a minha Pátria que tem direito a reclamá-los e que possa ter o prazer preenchidos os deveres que devem caracterizar o homem de bem que por tantos motivos deve amar o seu Principe....», para, na carta de 29 do mesmo mês, explicar ainda melhor o seu pensamento e a sua satisfação por os acontecimentos em Portugal poderem pôr «ao abrigo de inimigos que de outra maneira querem formar o mundo a seu modo....».

$\mathrm{Na}$ sequência dessa reflexão escreve: «Deus queira de uma vez acabar com semelhantes indivíduos.... que não calculam - mal, conduzem a Pátria a males imagináveis de que certamente os nossos inimigos aproveitarão», esclarecendo: "Os inovadores criticam-nos de seguirmos as pisadas dos nossos maiores, querem que o governo se organize de outra forma».

As suas preocupações aumentam, tanto que «a um tempo a esta parte temos observado que as correspondências diferem das vossas em pontos essenciais, que poderão ao futuro produzir males maiores ao nosso reino.... e como temos a grande desgraça de termos distantes os nossos Imperantes, as providências são tardias e muitas vezes já não podem obstar aos males que ganhando raiz o remédio é incerto».

Estas cartas, de um enviado da Junta, revelam o ambiente e o. panorama que ele encontrou em Londres junto dos emigrados e que não corresponde aos seus próprios pontos de vista. Podemos conhecer como a proposta de uma outra organização de governo era motivo de discussão e talvez de azedume entre 
portugueses no exílio e portugueses diplomatas ou enviados especiais e como essa outra posição podia, de alguma forma, ser coincidente com as preocupações e propostas do grupo de Lisboa, na percepção da necessidade de uma nova organização política de base constitucional.

7. Esta questão, como problema teórico e como solução prática, vai ter uma longa gestação. Ela é, porém, constatada como uma necessidade a partir do momento em que a Junta se reúne e se responsabiliza pelas tarefas governamentais. Perante as questões de administração, das rendas públicas e da manutenção da máquina do Estado, e uma vez que «os imperantes» se mantêm longe da Pátria, não há outro remédio senão ser o povo todo ou os seus representantes a governar.

A questão da soberania, que ninguém quer discutir, entronca na resolução das questões práticas. $\mathrm{E}$ não me interessa discutir, neste momento, se a Junta se une em torno de um projecto ideológico anti-francês, isto é, anti-revolução francesa, porque esse pode ser um aspecto emotivo, já que profundamente ele encerra uma afirmação de soberania (entendida como patriotismo) e de legitimidade não só ccntra o invasor, mas contra as decisões do Príncipe - que não cumpria o Pacto. Se fosse preciso encontrar uma teoria para legitimar esta prática seria fácil encontrá-la em Hobbes, porque quando Hobbes defende o poder absoluto, fá-lo em nome e no interesse dos indivíduos, da sua segurança, conservação e paz. Hobbes seculariza o poder e demonstra-lhe, não a majestade, mas a utilidade.

Se os componentes da Junta do Porto não tinham lido Hobbes, ainda assim, seguem-lhe o pensamento e, por isso, não pretendem dissolver o Contrato, mas assumem a soberania, não em espírito sedicioso, mas perante a necessidade.

Perante a ineficácia da casa reinante e do seu governo e perante o vazio do poder, os grupos próximos do poder vão estabelecer novo pacto. Os portugueses cortesãos, os comerciantes, os militares ou os intelectuais, precisavam de encontrar o seu próprio e adequado interlocutor. Serão os mais revolucionários, no domínio das ideias, os que sabem viver sem o rei, assumindo as responsabilidades em seu lugar. No campo da prática política é o caso da Junta do Porto, de 1808, que assume esse papel, sem, no entanto provocar uma ruptura epistemológica. A Junta é fiel ao rei e aos princípios monárquicos, não fala de constituição, age em nome do rei sem o ter consultado e contraria as suas ordens expressas de aceitação da invasão. A evolução do papel desta Junta no desenrolar dos acontecimentos ligados ao liberalismo português, tem levado a histo- 
riografia a negligenciar a análise desta primeira tomada de posição, que, afinal, fundamenta qualquer tomada de posição contra as decisões do rei. O pacto pode não ser denunciado, em relação à pessoa do rei, mas é-o nos seus aspectos mais profundos, na questão de soberania. Quem decide é quem detém a soberania. A fractura com o antigo regime vai estabelecer-se. Verifica-se que não é um acto isolado e deliberado. É produto dos acontecimentos e das contradições de um regime já sem soluções para a sociedade em crise. 